\title{
A GIS APPROACH TO IDENTIFY THE CORK OAK DECLINE IN M'SILA FOREST (NORTH-WEST OF ALGERIA)
}

\author{
Ghefar Mohammed*and Dehane Belkheir \\ Department of Agricultural Sciences and Forestry, Laboratory Conservatory \\ Management of Water, Soil and Forests, Rocade1, University Abou Bekr Belkaid \\ Tlemcen, Algérie. \\ *Corresponding author: Ghefar Mohammed \\ mohamedghfr@gmail.com
}

(Received January 2018 - Accepted April 2019)

\begin{abstract}
Ghefar, M. and Dehane, B. 2019. A GIS approach to identify the Cork Oak Decline in M'Sila Forest (North-West of Algeria). Lebanese Science Journal. 20(2): 206-214.

The decline of cork oak trees in North-West of Algeria was supposed to be caused by a combination of primary or predisposing factors, and secondary or opportunistic factors. There is a broad consensus about the role of water scarcity and nutrients in the primary causes, given the similarity of symptoms of cork oak decline and of chronic water deficits. To identify and characterize the cork oak decline in M'sila forest, a cork oak mortality index was determined for each transience area using a GIS approach and a linear regression model formulated by analyzing the interactions between the attributes of station (competition of superior and inferior floor); and allowing a justification of cork oaks mortality. The mortality index is significantly high in the invasive shrub plots and where the Aleppo pine density is very high; in which competition for soil water between the trees and the inferior floor increases. The lowest mortality value characterized by a lower density of Aleppo pine and herbaceous inferior floor.
\end{abstract}

Key words: Land cover, decline, cork oak, mortality, competition, and understory.

\section{INTRODUCTION}

Quercus suber is one of the most important species in the Mediterranean forest and cork is one of the few forest products with a positive trade balance in the western Mediterranean basin. The total world cork exports reached 1,484.4 million euros and more than 200.000 Tx in 2010 (APCOR., 2018). 
Cork oak forests are of crucial importance to the economy and ecology of several Mediterranean countries, covering an area of 2,139,942 hectares worldwide (APCOR., 2018) a large part of which is located in rural areas threatened by human desertification.

Over the recent decades, cork oak has witnessed a significant loss of strength in the cork producing regions, notably in north of Africa. This complex phenomenon related to various factors and varying intensity from a region to another: exceptional droughts, unfavourable edaphic conditions, absent or inadequate silvicultural practices, fires, insect attacks and other parasites (Amandier., 2006).

Mediterranean cork oak forest has been affected by this phenomenon since the beginning of the 20th century (Natividade., 1956). However, it began to take on relatively large dimensions from the 1980s to the 1990s.

In north-west Algeria, the decline of this valuable species has been little studied. In M'Sila it was reported in 1891 and it was only in 1975 that this phenomenon attracted the attention of local foresters (Dehane., 2012).

The diagnosis and determination of the underlying causes did not really begin until the 1980s. Several missions were organized on site between 1983 and 1995 (Abbas and Aici., 1989). During this period, a marked increase in dieback was observed in the form of spots appearing across all stands. (Bouhraoua., 2003).

The present work aims at elucidating the phenomenon of Quercus suber decline: in relation to the possible competition from superior and inferior floors. Also determining cork oak mortality at landscape level using remote sensed data, and the probability to find an area with cork oak mortality based on linear regression model using station attributes.

\section{MATERIALS AND METHODS}

\section{Study area}

The study area covering 900 ha was realized in the cork oak forest of M'sila, located in the northwestern part of Algeria (Figure 1). The climate is Mediterranean with a semi-arid, characterized by an annual temperature varied from 15 to $25^{\circ} \mathrm{C}$ and the rainfall does not exceed $400 \mathrm{~mm}$ per year. This forest massif is composed of natural stands of pure cork oak or mixed stand with Aleppo Pine. There are only a few traces of natural regeneration. The rest of the massif is occupied by stands of Aleppo pine or shrubs. 


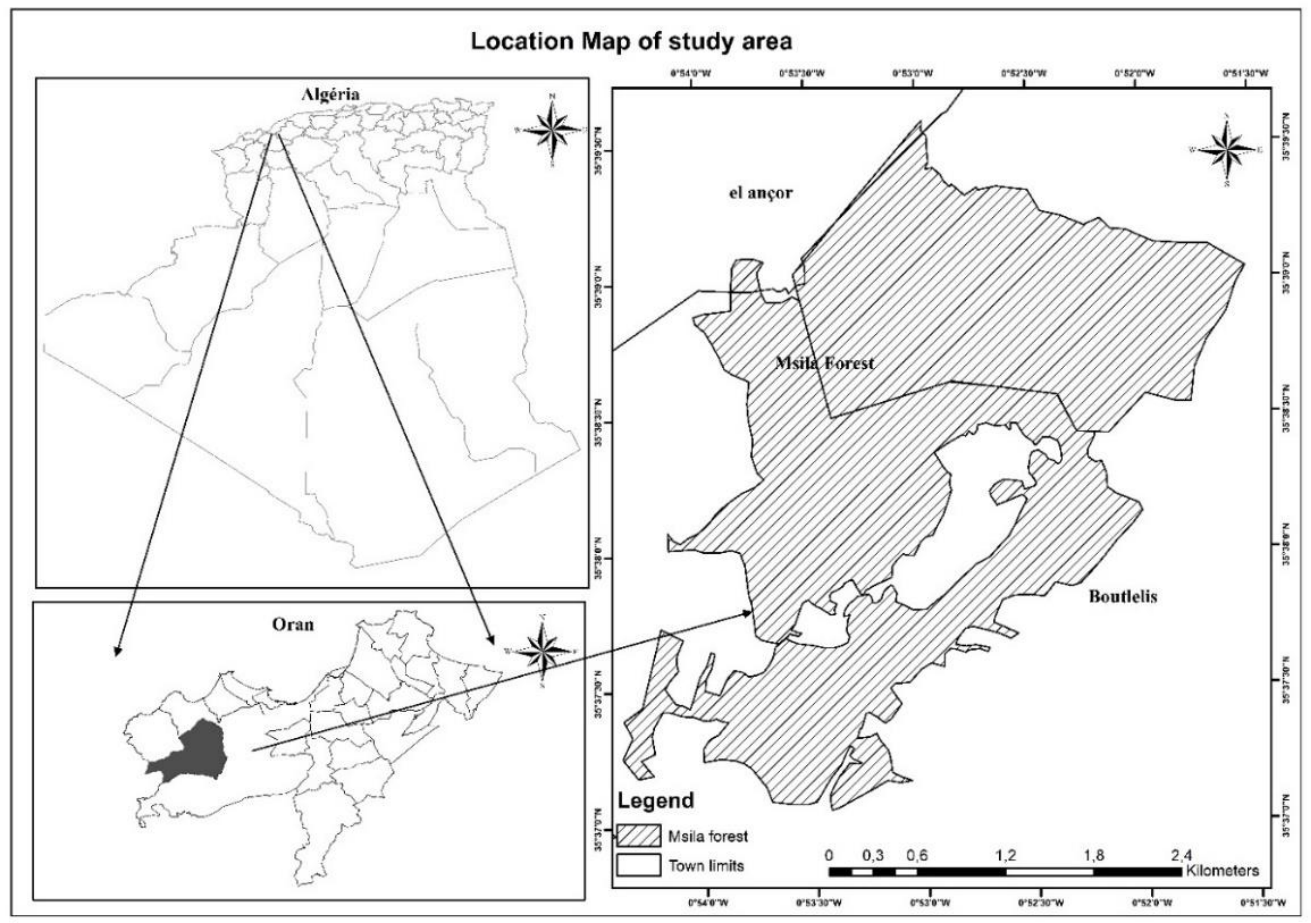

Figure 1. Location map of study area (M'sila Forest).

In this study we used a satellite image with high spatial resolution $(2,5 \mathrm{~m})$ obtained from the satellite Alsat $2 \mathrm{~B}$ and digital aerial photos $0,5 \mathrm{~m}$ spatial resolution. This combination of information was used to analyse the landscape composition, delineate the cork oak land and identify the cork oak mortality areas. We also developed a spatial model of the cork oak mortality, based on ordinary least squares with GIS (Geographies information system) variables.

In the cartography analysis, we considered the following landscape composition classes: cork oak land, pineland, shrub, and agriculture lands. The landscape composition estimated by the sum of areas covered by each class that was classified and mapped using the remote sensed data and confirmed by direct field observation.

\section{Land cover and mortality classification}

At the time of the field inventory, the Quercus suber mortality area defined as the area with occurrence of oak decline symptoms such as crown thinning, discoloration of 
leaves, crown reduction and tree dehydration, in single trees, or in small areas within the stands.

Cork oak mortality classified into three categories: C1: no mortality (less than or equal to one dead tree per hectare), C2: with normal mortality (between 1 to 5 dead trees per hectare) C3: with High mortality (more than 5 dead trees per hectare).

We calculated the cork oak mortality index (MI) for each class based on the below equation (Augusta and al., 2010).

$$
\mathrm{MI}=\operatorname{Int}\left\{\frac{\sum_{i=1}^{n} a_{k i}}{A_{k}} * 10\right\}
$$

Where: aki is the area of the patch i classified "with mortality" of the class k, $\mathrm{Ak}$ is the total patch area of the class $\mathrm{k}$

$\mathrm{n}$ is the number of patches "with mortality" of the class $\mathrm{k}$

A spatial database was constructed including the competition of a superior floor defined by the density of Aleppo Pine distributed over four classes: $\mathrm{C} 1$ : low: $<50$ trees per ha; C2: medium 50 to 100 trees per ha; C3: high 100 to 200 trees per ha; C4: very high > 200 trees per ha. Moreover, the competition of an inferior floor was also subdivided into four classes and defined as $\mathrm{C} 1$ : dominated by annual/biannual herbaceous; $\mathrm{C} 2$ : Dominated by low-intensity shrubs; C3: dominated by encroaching shrub species; C4: Dominated by bush.

The correlation between cork oak mortality and spatial patterns assessed in a randomly selected sample of cork oak patches. The sampling approach, based on a balanced experimental design with a number of patches, was proportional to the covered surface in each landscape stratum.

A linear regression model using the ordinary least square (Arcgis 10.2) modelled the above referred to GIS Data and selected a set of independent variables (superior floor and inferior floor) which could explain, in a logical and statistically significant way, the probability of the cork oak mortality in a given site. Therefore, the cork oak mortality probability model was applied to the total cork oak area.

\section{RESULTS}

Our observation showed that in M'sila area woodlands are is the dominant land use, followed by the shrub lands and the agriculture areas (Figure 2). Woodlands 
corresponded to $50 \%$ of the total area of the study, while the shrub lands and the agriculture represented $32 \%$ and $18 \%$ respectively.

Cork oak was the dominant landscape stratum occupying 242 ha of the area followed by the pine stratum with 216 ha. The cork oak lands were mostly uneven-aged mature stands that resulted from the management of naturally regenerated stands with a large percentage of trees under cork exploitation. More than half of the cork oak area represents an irregular formation mixed with Aleppo pine with an average of 80 trees per ha. The dominant understory was herbaceous (42\%), corresponding of the cork oak pure woodlands area. Shrub encroachment was found in $30 \%$ of the cork oak woodlands, while the bushes were observed in the third row represented by regenerations of Aleppo pine and Arbutus tree in clear plots.

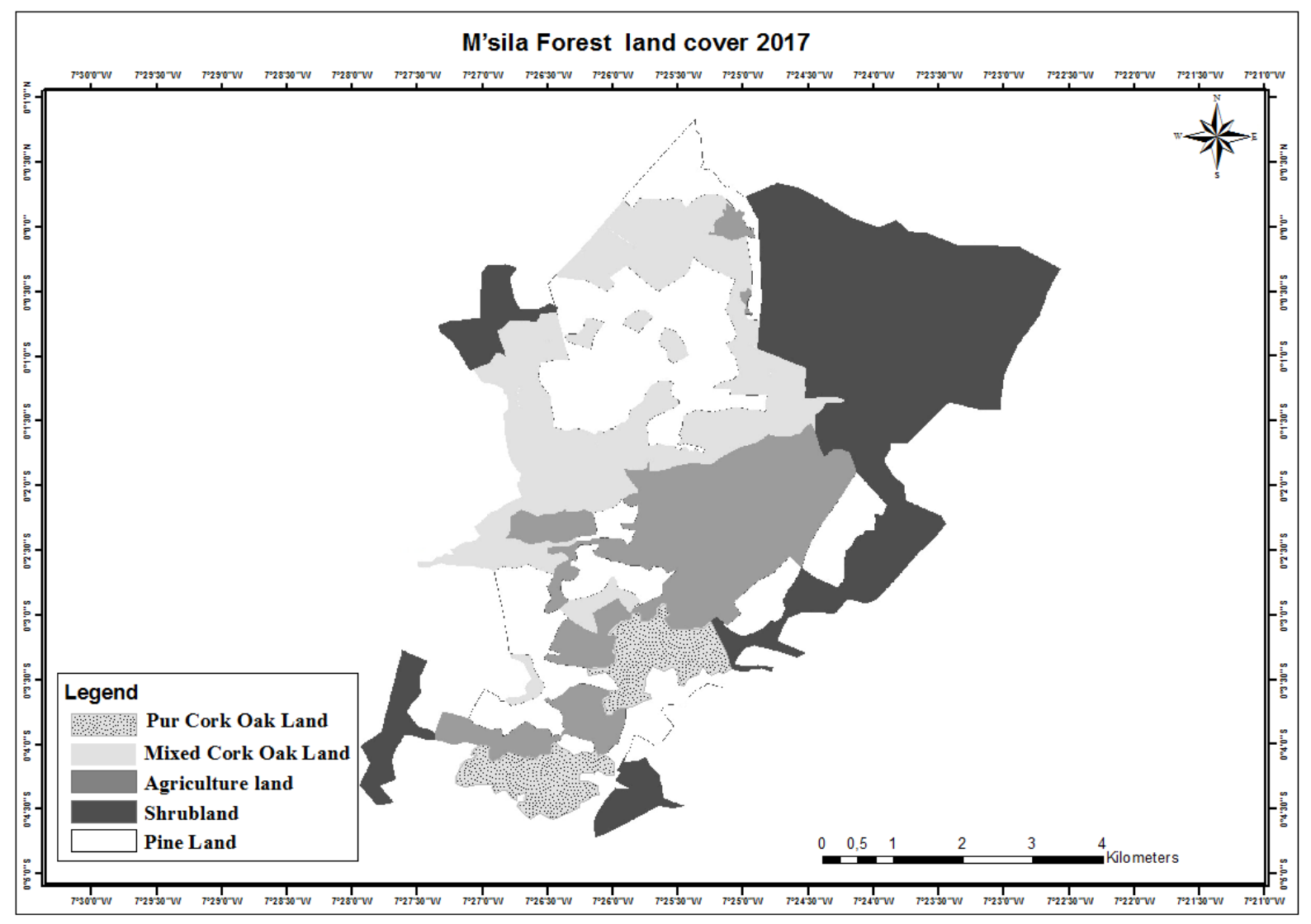

Figure 2. M'sila land cover 2017. 
The overall mortality index (MI) of the cork oak area was C3, but with a distinct occurrence between pure and mixed cork oak. The mortality index was highest in areas where Aleppo pine is dominant and decreased in areas where cork oak dominated.

The cork oak mortality index was also significantly different in the three types of understory. The MI increased threefold in areas with shrub encroachment in comparison with intrusion with shrub bush or with herbaceous communities. The highest value (MI =3) was found in areas with shrub encroachment and where the density of Aleppo pine is very high (Class 03 and Class 04) and the lowest value in M'sila forest characterized by a lower density of Aleppo pine and herbaceous understory corresponded to $(\mathrm{MI}=2)$.

The ordinary least square model with selected GIS variables was built with a $\mathrm{R}^{2}=0,95$ significant at $\mathrm{p}<0.05$. All variables included in the logistic model were significant according to the Wald test $\left(0.000000^{*}\right)$ and the Koenker test $\left(0.000060^{*}\right)$. (Table 1)

Table 1. Regression coefficient of mortality.

\begin{tabular}{|l|l|l|l|l|l|}
\hline Variables & T-Test & Pr robust & Coefficient & $\begin{array}{l}\text { Standard } \\
\text { Deviation }\end{array}$ & Significance \\
\hline Superior floor & 5,13 & $0.000022^{*}$ & 0.004229 & 0.000725 & $0.000000^{*}$ \\
\hline Inferior floor & 2,51 & $0.020441^{*}$ & 0.207201 & 0.0082300 & $0.000000^{*}$ \\
\hline
\end{tabular}

The two variables included in our test were significant according to the T-test, the robust probability and according to the calculated regression coefficient. They represent a positive and strong relationship (Figure 3 ). 


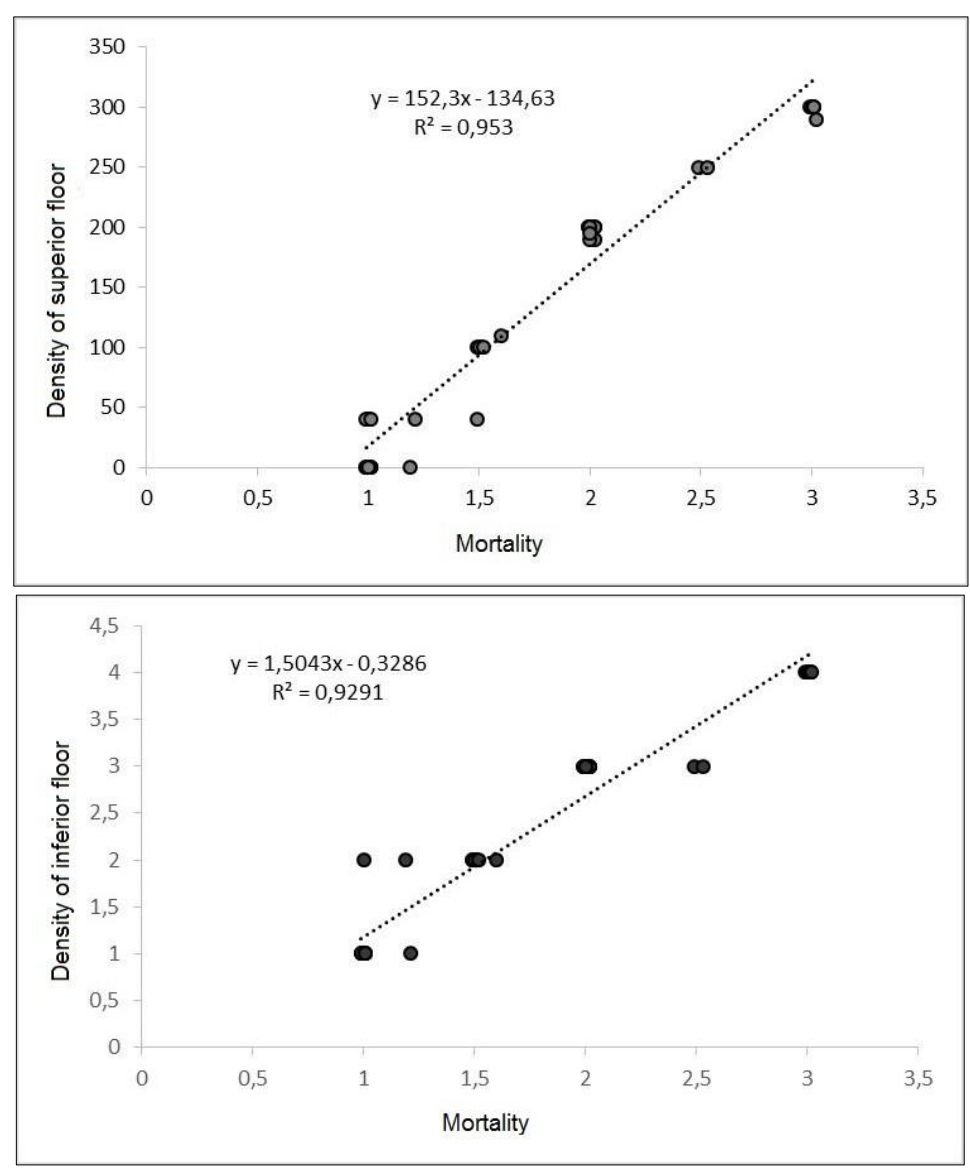

Figure 3. Relationship between cork oak mortality and competition of superior and inferior floors.

Considering the two tested variables, the superior floor was the maximum value that affected the cork oak mortality with 0.95 probability. The cork oak mortality (C3) was in the class 04 and 03 of the superior and inferior floor competition respectively. In this case, the normal mortality was in the class 02 of competition and in plots dominated by low-intensity of shrubs. Otherwise, mortality is absent in pure cork oak plots and in areas with low Aleppo pine density and herbaceous understory.

\section{DISCUSSION}

The present study showed that Quercus suber mortality in M'sila conditions related to landscape features, the distribution of decline consistently suggested that site conditions, which directly influence the tree water availability, are stressful landscape 
factors that contribute to the onset of cork oak mortality. This is in agreement with reported findings for deciduous oaks in the south-eastern United States (Kabrick et al., 2008; Oak et al., 1996).

In M'Sila forest, the most of cork oak mortality was found in areas with a dense canopy cover and with shrub encroachment, the lowest in areas with a clear canopy cover and herbaceous understory. Those patterns may also be associated with the findings for encroached holm oak "dehesas", where a significant increase in competition between trees and understory for soil water and nutrients was observed when compared with cropped "dehesas" (Cubera et al., 2004).

In cork oak forest, it is insufficient to predict mortality at a patch level using only variables related to understory and canopy cover. Nevertheless, the model emphasized the importance of competition on cork oak mortality. It was correctly identifying the spatial and structural features of the areas and revealed the reasons for the highest incidence of cork oak mortality.

To increase expectancy, tree-related variables must be add to the model and reported as significant predictors of mortality. Such driving forces can be: tree vigour, age, biometric characteristics, and intensity of cork exploitation.

\section{CONCLUSION}

In M'Sila forest, cork oak mortality is more likely to occur in unmanaged areas, overall, the site attributes consistently associated with cork oak mortality were those that contribute to tree water stress, inhibit either a deep root development or the access to groundwater.

The management system and landscape features should be used with logistic regression procedures to identify "sensitive areas" for cork oak mortality, which can be used for preventive planning and mitigations measures.

\section{BIBLIOGRAPHIC REFERENCE}

Abbas M., Aici M., \& Khous M.G. 1989. Note sur la protection des subéraies. Journée d'étude sur le chêne-liège. 6 pp.

Amandier, L. 2006. Les causes de dépérissement du chêne liège et de chêne vert. Séminaire Vitalité des peuplements des chênes liège et des chênes vert : situation actuelle, état des connaissances et actions à entreprendre. Evora, Portugal, 3 pp. 7. 
Apcor. 2018. Boletim estatístico da cortiça | cork 2017/2018, Portugal, pp.100

Augusta Costa, Helena Pereira, Manuel Madeira. 2010. Analysis of spatial patterns of oak decline in cork oak woodlands in Mediterranean conditions. Annals of Forest Science, Springer Ver- lag/EDP Sciences, 67.

Bouhraoua, R. T. 2003. Situation sanitaire de quelques forêts de chêne liège de l'ouest algérien. Etude particulière des problèmes posés par les insectes. Thèse. Doct. Dept. Forest. Fac. Sci., Univ. Tlemcen, 267pp.

Cubera E.,Montero M.J., and Moreno G. 2004. Effect of land use on soil water dynamics in dehesas of Central-Western Spain. In: Schnabel, S. and Ferreira, A. (Eds.), Sustainability of agrosilvopastoral systems dehesas, montados, Advances in GeoEcology 37, Catena Verlag, Reiskirchen, pp. 109-123.

Dehane, B. 2012. Incidence de l'état sanitaire des arbres du chêne-liège sur les accroissements annuels et la qualité du liège de deux subéraies oranaises : m'sila (w.oran) et zarieffet (Tlemcen). Thèse. Doc. Dept. Forest. Fac. Sci., Univ. Tlemcen. pp 363.

Kabrick J.M., Dey D.C., Jensen R.G., and Wallendorf M. 2008. The role of environmental factors in oak decline and mortality in Ozark Highlands. For. Ecol. Manage. 255 $\mathrm{pp}$

Natividade, J. V. 1956. Subericulture. Ecole Nationale des Eaux et Forêts. Nancy, 302 Pereira,

Oak S., Tainter F., Williams J., and Starkey D. 1996. Oak decline risk rating for the Southeastern United States, Ann. Sci. For. 53: 721-730. 